\title{
Bioefficacy of Nova Nutri Boost for Yield and Yield Components in Paddy (Oryza sativa L.)
}

\author{
N. Basanth and G. Mahesh* \\ Nova Agri Tech Pvt. Ltd. New Bowenpally, Secunderabad, Telangana - 500011, India \\ *Corresponding author
}

\section{A B S T R A C T}

\begin{tabular}{|l|}
\hline Ke y w o r d s \\
$\begin{array}{l}\text { Paddy (Oryza sativa } \\
\text { L.), Bioefficacy, Nova } \\
\text { Nutri Boost, Yield }\end{array}$ \\
\hline Article Info \\
\hline $\begin{array}{l}\text { Accepted: } \\
\text { 18 September } 2018 \\
\text { Available Online: } \\
\text { 10 October } 2018\end{array}$ \\
\hline
\end{tabular}

An investigation was carried out during kharif, 2018 in rice crop by application of Nutri Boost an amino powered yield booster at different stages of crop growth to mode of action and appropriate time of application in Telangana. The experiment was laid out in Randomized Block Design (RBD) with five treatments and control i.e. $\mathrm{T}_{1}$ : control, $\mathrm{T}_{2}$ : $2.5 \mathrm{ml} / 1$ Nutri Boost through foliar spray @ 20 DAT, $\mathrm{T}_{3}: 2.5 \mathrm{ml} / 1$ Nutri Boost through foliar spray@ 45 DAT, T 4 : 2.5ml/1 Nutri Boost through foliar spray @ 70 DAT, T $: 2.5 \mathrm{ml} / 1$ Nutri Boost through foliar spray @ 20 and 45 DAT, T 6 : 2.5ml/1 Nutri Boost through foliar spray@20 and 45 and 70 DAT. Experiment revealed that application of $\mathrm{T}_{6}(2.5 \mathrm{ml} / 1 \mathrm{Nutri}$ Boost@ 20,45 and 70 DAT) and $\mathrm{T}_{5}(2.5 \mathrm{ml} / 1$ Nutri Boost through foliar spray @ 20 and 45 DAT) resulted in improved plant height, leaf area index, number of tillers per square meter, panicle length, spikelet fertility (\%), test weight, harvest index, grain yield and straw yield compared to other treatments. There is no significance difference between $\mathrm{T}_{5}$ and $\mathrm{T}_{6}$ except for spikelet fertility $(\%)$, test weight, grain yield and harvest index.

\section{Introduction}

India is mainly known for its agricultural productivity. In order to get a better harvest and to enhance the plant growth, farmers use fertilizer in the soil. The fertilizers can be Chemical fertilizers or Bio fertilizers. Among these two, Bio fertilizers play a crucial role in maintaining soil fertility and essential components that are needed for organic farming (Sasireka et al., 2016). Nowadays, plant and humus extracts have been replaced in agriculture to enhance the plant growth because it acts as biostimulants and bio fertilizers. It contains promoters, plant growth regulators while other macronutrients and micronutrients along with amino chelates which promote faster seed germination and increase in yield. These extracts are natural amino chelates which promotes faster seed germination and uptake of micro nutrients by plants. Amino acids have a chelating effect on micro nutrients, when applied together with micro nutrients, the absorption and transport of micronutrients inside the plants is easier. It is eco-friendly for sustainable agriculture. Compare to routine fertilizers or other commercially synthetic chelators such as EDTA; however amino chelates represents a safer and more efficient form of fertilizer resulting in better plant performance and less environmental risk (Mohammad Kazem Souri, 
2016). The application of plant extracts in crops as foliar spray, fertigation, root drench or seed treatment are mainly focused in many research aspects. Treatment with these increases nutrient uptake of soil and makes them resistant to environmental stress (frost and wind). The most promising and advantageous of Plant and humus-derivedfertilizers in agriculture is to enhance growth rate, nutrient uptake, shoot and root development and to make the plants resistant to climate and pests. Most of the research works that has done so far concentrated on above. This research work provides information concerning different aspects of amino chelate fertilizers including their value and effect on paddy. Here, bio efficacy of Nova Nutri Boostan amino powered yield booster was evaluated in five different times against control to find better efficiency and faster growth rate to get increased yield.

\section{Materials and Methods}

Field experiments were conducted in the rainy season of 2018 at the Nova Agritech Pvt. Ltd. Experimental farm (Latitude 18.3131848 Longitude 78.2544944), Kamareddy, Telangana, India to determine the effects of Nova Nutri Boost an amino chelate contains iron, manganese, zinc, boron which will effect on growth, development, yield and yield components of rice. The experiments were laid out in Randomized Block Design (RBD) with three replications the treatments comprised of five dates of applications vis; $\mathrm{T}_{1}$ : controle, $\mathrm{T}_{2}: 2.5 \mathrm{ml} / 1$ Nutri Boost through foliar spray @ 20 DAT, T 3 : 2.5ml/1Nutri Boost through foliar spray @ 45 DAT, T4:2.5ml/1 Nutri Boost through foliar spray @ 70 DAT, $\mathrm{T}_{5}: 2.5 \mathrm{ml} / 1$ Nutri Boost through foliar spray @ $20 \&$ 45DAT, $\mathrm{T}_{6}: 2.5 \mathrm{ml} / 1$ Nutri Boost through foliar spray @ $20 \& 45 \& 70$ DAT. The rice was planted first in nursery and later thinned at four weeks old and transplanted within average of three seedlings per hill on prepared seed beds, at $20 \mathrm{~cm} \times 20 \mathrm{~cm}$ within and between rows. Data was recorded on established plants using averages of two quadrate $(20 \mathrm{~cm} \times 20 \mathrm{~cm})$ throws at 8 weeks after planting, leaf area by using portable leaf area meter in $1 \mathrm{~m}^{2}$ area, days to $50 \%$ flowering, plant height at maturity and no. tillers per $\mathrm{m}^{2}$ on five tagged plants were recorded. Plants at maturity were manually harvested within $10 \mathrm{~m}^{2}$ area from base, bound, air dried, panicles separated from stalks, manually threshed, winnowed and recovered paddy weighed and recorded as paddy yield per hectare and 1000 seed weight as test weight. The straw was then weighed and recorded as weight per square area.

\section{Treatments}

$\mathrm{T}_{1}$ : controle,

$\mathrm{T}_{2}: 2.5 \mathrm{ml} / 1$ Nutri Boost through foliar spray @ 20 DAT,

$\mathrm{T}_{3}: 2.5 \mathrm{ml} / 1$ Nutri Boost through foliar spray @ 45 DAT,

$\mathrm{T}_{4}: 2.5 \mathrm{ml} / 1$ Nutri Boost through foliar spray @ 70 DAT,

$\mathrm{T}_{5}: 2.5 \mathrm{ml} / 1$ Nutri Boost through foliar spray @ $20 \& 45$ DAT,

$\mathrm{T}_{6}: 2.5 \mathrm{ml} / 1$ Nutri Boost through foliar spray @ $20 \& 45 \& 70$ DAT

\section{Results and Discussion}

The findings in the present study as well as relevant discussion have been presented under following heads.

\section{Plant height}

The plant height ranged from 93-110 cm. Among the various times of Nutri Boost 
application Nutri Boost @ $2.5 \mathrm{ml} / \mathrm{l}$ at 20, 40 \& 70 DAT $\left(\mathrm{T}_{6}\right)$ accounted for significantly higher plant height of $110 \mathrm{~cm}$.

\section{Leaf area index}

LAI ranged from 3.2-4.4. Among the various times of Nutri Boost application Nutri Boost @ $2.5 \mathrm{ml} / 1$ at 20, 40\&70 DAT $\left(\mathrm{T}_{6}\right)$ accounted for significantly higher LAI of 4.4.

\section{Panicle length}

Panicle length ranged from 19.9-24.1 cm. Among the various times of Nutri Boost application Nutri Boost @ $2.5 \mathrm{ml} / \mathrm{l}$ at 20, 40\&70 DAT $\left(\mathrm{T}_{6}\right)$ accounted for significantly higher panicle length of $24.1 \mathrm{~cm}$. Waseem raza et al., (2008) reported that foliar application of amino acid@1/100 dilution of amino acid chelated $\mathrm{Zn}$ and Fe fertilizer increased growth parameters from $22-77 \%$.

\section{Spikelet fertility \%}

Spikelet fertility\% ranged from 82-98\%. Among the various times of Nutri Boost application Nutri Boost @ $2.5 \mathrm{ml} / \mathrm{l}$ at 20,40 \& 70 DAT $\left(\mathrm{T}_{6}\right)$ accounted for significantly higher panicle length of $24.1 \mathrm{~cm}$. Indira Chathurvedi (2006) reported that application of recommended $\mathrm{NPK}+\mathrm{Mn}+\mathrm{B}+\mathrm{Zn}$ significantly increased spikelet fertility $\%$ and boron had vital role on the grain set in rice.

\section{Test weight}

Test weight ranged from 28.3-32.6g. Among the various times of Nutri Boost application NutriBoost@2.5 ml/1 at 20,40\&70 DAT $\left(\mathrm{T}_{6}\right)$ accounted for significantly higher test weight of $32.6 \mathrm{~g}$. Indira Chathurvedi (2006) reported that application of recommended NPK $+\mathrm{Mn}+$ $\mathrm{B}+\mathrm{Zn}$ significantly increased test weight by $16.60 \%$.

Table.1 Effect of different levels of Nutri Boost on yield and yield components in rice

\begin{tabular}{|c|c|c|c|c|c|c|c|c|c|c|c|}
\hline Characters & $E$ & 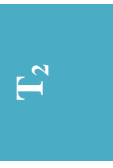 & $F$ & $E$ & E & $=$ & 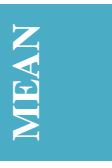 & $\begin{array}{l}\bar{r} \\
\text { a }\end{array}$ & 용 & $\vec{ن}$ & se \\
\hline Plant height (cm) & 93 & 96 & 102 & 97 & 108 & 110 & 101.0 & 2.81 & 4.2 & 2.29 & 18.28 \\
\hline Leaf area index & 3.2 & 3.8 & 4.1 & 3.9 & 4.29 & 4.4 & 3.9 & 0.18 & 0.44 & 6.09 & 37.50 \\
\hline Days to $50 \%$ flowering & 88 & 89 & 90 & 88 & 90 & 82 & 87.8 & 1.22 & NS & 3.29 & -6.82 \\
\hline No. of tillers $/ \mathrm{m}^{2}$ & 179.10 & 221 & 210 & 180 & 232 & 241 & 210.5 & 10.68 & NS & 4.14 & 34.56 \\
\hline Panicle length $(\mathrm{cm})$ & 19.93 & 20.5 & 23.3 & 22 & 23.7 & 24.1 & 22.3 & 0.71 & 1.96 & 4.84 & 20.92 \\
\hline Spikelet fertility \% & 82.04 & 88.3 & 91.3 & 93.3 & 95 & 98 & 91.3 & 2.29 & 2.81 & 1.69 & 19.45 \\
\hline Test weight (g) & 28.25 & 29 & 30.2 & 31.5 & 31 & 32.6 & 30.4 & 0.66 & 1.2 & 2.16 & 15.40 \\
\hline Grain yield $\left(\mathrm{t} . \mathrm{ha}^{-1}\right)$ & 2.87 & 3.01 & 3.23 & 3.2 & 3.8 & 4.0 & 3.4 & 0.18 & 0.33 & 5.39 & 39.37 \\
\hline Straw yield $\left(\mathrm{t} . \mathrm{ha}^{-1}\right)$ & 4.07 & 4.11 & 4.19 & 4.15 & 4.39 & 4.42 & 4.2 & 0.06 & 0.13 & 1.74 & 8.60 \\
\hline Harvest Index & 0.368 & 0.422 & 0.435 & 0.435 & 0.458 & 0.475 & 0.4 & 0.02 & 0.03 & 3.58 & 29.08 \\
\hline
\end{tabular}

\section{Grain yield}

Grain yield ranged from 2.87-4 t.ha ${ }^{-1}$. Among the various times of Nutri Boost application NutriBoost @ $2.5 \mathrm{ml} / 1$ at 20, 40 \& 70 DAT $\left(\mathrm{T}_{6}\right)$ accounted for significantly higher grain yield of 4.0 t.ha ${ }^{-1}$. Indira chathurvedi (2006) reported that application of recommended
$\mathrm{NPK}+\mathrm{Mn}+\mathrm{B}+\mathrm{Zn}$ significantly increased seed yield by $47.6 \%$.

\section{Straw yield}

Straw yield ranged from 4.1-4.4 t.ha ${ }^{-1}$. Among the various times of Nutri Boost application Nutri Boost @ $2.5 \mathrm{ml} / \mathrm{l}$ at 20, 40 \& $70 \mathrm{DAT}\left(\mathrm{T}_{6}\right)$ 
accounted for significantly higher straw yield of 4.4 t.ha ${ }^{-1}$.

\section{Harvest index}

Harvest index ranged from 0.37-0.48. Among the various times of Nutri Boost application Nutri Boost @ $2.5 \mathrm{ml} / \mathrm{l}$ at 20, 40 \& $70 \mathrm{DAT}\left(\mathrm{T}_{6}\right)$ accounted for significantly higher harvest index of 0.48. Zayed et al., (2011) reported that micronutrient application significantly increase the harvest index.

Application of $2.5 \mathrm{ml} / 1$ Nutri Boost through foliar spray @ 45 DAT $\left(\mathrm{T}_{3}\right)$ produced more plant height, leaf area index, panicle length, grain yield, straw yield, than in $T_{1}, T_{2}$ and $T_{4}$ Zayed et al., 2011 reported that leaf area index as well as plant height and panicle length were significantly higher when rice plant received the micronutrient rather compared to the control. Application of $2.5 \mathrm{ml} / 1$ Nutri Boost through foliar spray $\left(\mathrm{T}_{4}\right)$ @ 70 DAT (grain formation stage) produced more 1000 grain weight than $\mathrm{T}_{1}, \mathrm{~T}_{2}, \mathrm{~T}_{3}$ and $\mathrm{T}_{5}$. Zayed et al., 2011 also reported that the combination of $\mathrm{Zn}^{+2}+\mathrm{Fe}^{+2}+$ $\mathrm{Mn}^{+2}$ gave the highest values of grain yield, straw yield, harvest index and yield components; panicle length, spikelet fertility (\%) and 1000-grain weight.

There is no significance difference between $\mathrm{T}_{5}$ $\& \mathrm{~T}_{6}$ except for spikelet fertility (\%), test weight, grain yield and harvest index.

Data presented in table 1 showed that application of $2.5 \mathrm{ml} / \mathrm{l}$ of Nutri Boost @ 20, 45, 70 DAT $\left(\mathrm{T}_{5}\right)$ resulted in improved plant height, leaf area index, number of tillers per square meter, panicle length, spikelet fertility (\%), test weight, harvest index, grain yield and straw yield compared to other treatments. Waseem raza et al., (2008) reported that foliar application of amino acid @ 1/100 dilution of amino acid chelated $\mathrm{Zn}$ and $\mathrm{Fe}$ fertilizer increased growth parameters from 22-77\%. Here it was concluded that application of 2.5 $\mathrm{ml} / 1$ of Nutri Boost @ 20,45 \& 70 DAT produced high values for grain yield and yield components in rice. It has increased the grain yield and harvest index of 39.4 and $29.1 \%$ respectively.

\section{References}

Indira Chathurvedi., 2006. The effect of micronutrients on yield attributes, yield and nutrient uptake of hybrid rice (Oryza sativa L.). Asian Journal of Biological Sciences 1(2):89-91.

Mohammad Kazem Souri, 2016. Aminochelate fertilizers: the new approach to the old problem; a review. Open Agriculture; 1: 118-123.

Sasireka, R., Sasikala, M., Indumathi, E., Radhika, S.2016. Effect of seaweed extract (Sargassum tenerrimum) on seed germination and growth of tomato plant (Solanum lycopersicum). International Journal of ChemTech Research. 9(9):285-293.

Waseem Raza M.J., Yuan Chun Xu and QiRong Shen. 2008. Preparation and optimization of amino acid chelated micronutrient fertilizer by hydrolyzation of chicken waste feathers and the effects on growth of rice. Journal of Plant Nutrition 31: 571-582.

Zayed B.A, Salem A.K.M and El Sharkawy H.M. 2011. Effect of different micronutrient treatments on rice (Oriza sativa L.) growth and yield under saline soil conditions. World Journal of Agricultural Sciences 7 (2): 179-184.

\section{How to cite this article:}

Basanth, N. and Mahesh, G. 2018. Bioefficacy of Nova Nutri Boost for Yield and Yield Components in Paddy (Oryza sativa L.). Int.J.Curr.Microbiol.App.Sci. 7(10): 2250-2253. doi: https://doi.org/10.20546/ijcmas.2018.710.259 